\title{
O DIREITO PENAL MILITAR APLICADO AO CORPO DE BOMBEIROS MILITAR DO ESTADO DO TOCANTINS (CBMTO): ESTUDO DE CASO DOS CRIMES MILITARES COMETIDOS PELOS INTEGRANTES DO CBMTO ENTRE OS ANOS DE 2006 E 2016
} RVD

\author{
THE MILITARY CRIMINAL LAW APPLIED TO THE TOCANTINS STATE MILITARY \\ FIREFIGHTERS (CBMTO): CASE STUDY OF MILITARY CRIMES COMMITTED BY \\ CBMTO MEMBERS BETWEEN 2006 AND 2016
}

\author{
Alex Matos Fernandes ${ }^{1}$ \\ Tarsis Barreto Oliveira ${ }^{23}$
}

\section{RESUMO}

O presente artigo visa demonstrar a aplicabilidade do Direito Penal Militar no âmbito do Corpo de Bombeiros Militar do Estado do Tocantins (CBMTO), fazendo uma análise dos Inquéritos Policiais Militares instaurados no intervalo de tempo, iniciando pela emancipação da Corporação da Polícia Militar do Estado do Tocantins. Busca evidenciar a necessidade da discussão do Direito Penal Militar, a partir do Direito Penal Comum, numa perspectiva que engloba os conceitos de crime militar, justiça militar da união e justiça militar estadual, das forças armadas e das forças auxiliares (militares estaduais). Há uma breve apresentação do que são os Corpos de Bombeiros e dos Bombeiros Militar; um breve histórico do CBMTO; uma debruçada sobre o tema Inquérito Policial Militar, definições e conceitos para uma melhor contextualização do que foi pesquisado e trabalhado durante a pesquisa e, por conseguinte, concentração na análise dos inquéritos levantados, na discussão dos resultados e na apresentação da conclusão ou considerações finais, quanto às circunstâncias, especificidades dos fatos apurados, e dos resultados a que chegou o encarregado, e o andamento na justiça

\footnotetext{
${ }^{1}$ Bacharel em Direito pela Universidade Federal do Tocantins. Especialista em Estado de Direito de Direito e Combate a Corrupção pela Escola Superior da Magistratura Tocantinense. e-mail: matos1771@gmail.com ORCID: https://orcid.org/0000-0001-5404-9377

2 Doutor e Mestre em Direito pela UFBA. Professor Associado de Direito da UFT. Professor Adjunto de Direito da UNITINS. Membro do Comité International des Pénalistes Francophones e da Association Internationale de Droit Pénal. e-mail: tarsisbarreto@uft.edu.br ORCID https://orcid.org/0000-0003-09318915

${ }^{3} 706$ Sul almaeda 21, n, 6 apto 503, Residencial Vila Romana, Plano Direitor Sul, Palmas- TO, CEP $77.022-402$
} 
https://doi.org/10.20873/uft.2359-0106.2020.v7n2.p335-358

militar, para, no final, apresentar algumas considerações quanto ao tema Direito Penal Militar, em especial no âmbito acadêmico, sua importância e a razão dessa necessidade para uma defesa mais eficaz dos militares que por vezes possam vir a cometer algum delito militar que acarrete indiciação ou acusação da prática de um crime militar, e não possam ficar indefesos ou terem uma defesa ineficaz.

Palavras-chave: Direito Penal Militar; Crime Militar; Inquérito Policial Militar; Direito Penal.

\begin{abstract}
This article aims to demonstrate the military criminal law within the Tocantins State Fire Department (CBMTO), analyzing the Military Police Investigations instituted without any time interval, starting with the emancipation of the Tocantins Military Police Corporation. . It seeks to highlight the need for discussion of Military Criminal Law, based on Common Criminal Law, in a perspective that encompasses the concepts of military crime, union military justice and state military justice, the armed forces and auxiliary forces (state military). There is a brief presentation of what the fire brigades and military firefighters are; a brief history of the CBMTO; research on the topic Military Police Inquiry, configurations and concepts for a better contextualization that was researched and worked on during a research and, by estimation, concentration on the analysis of investigations raised, on the discussion of results and on the conclusion of the conclusion or final considerations, as to to the circumstances, specificities of the facts found, and the results reached or executed, and the progress in military justice, to, not final, presenting some considerations on the topic Military Criminal Law, especially in the academic field, its importance and the reason This has led to the need for a more effective defense of the military, which may at times commit a military offense leading to the indication or prosecution of a military crime, and may not be defenseless or ineffective in defense.
\end{abstract}

Keywords: Military Criminal Law; Military crime; Military Police Inquiry; Criminal law.

\title{
1 INTRODUÇÃO
}

O objeto deste artigo é abordar o Direito Penal Militar aplicado ao Corpo de Bombeiros Militar do Estado do Tocantins (CBMTO), analisando os crimes militares cometidos pelos militares da Corporação. Assim, a pesquisa se preocupou em responder quais são os crimes militares cometidos no âmbito do Corpo de Bombeiros Militar do Estado do Tocantins, entre 2006 e 2016, sua natureza e especificidades. O Direito Penal está no domínio do direito em foco no estudo. A pesquisa foi bibliográfica e documental, análise dos Inquéritos Policiais Militares.

O Direito Penal Militar, cujo objeto central é o crime militar, tem sua origem próxima ao Direito Penal comum, e quando se estuda suas origens, é possível verificar 
https://doi.org/10.20873/uft.2359-0106.2020.v7n2.p335-358

que essa distinção hoje perceptível nem sempre foi tão bem definida. Assim, quando o Direito Penal Militar é abordado, o Direito Penal comum é percebido com suas nuances e conceitos, muitos deles absorvidos pelo Direito Castrense, mas que, embora absorva aquele, distancia-se deste por meio de uma cisão entre ambos os domínios do Direito.

O crime militar, objeto do Direito Penal Militar, por sua vez, como muitos outros crimes, não é definido na Constituição Federal (art. 5ํㅡ, LXII), que traz apenas que o crime militar deve ser definido por lei própria. Assim, deve-se recorrer à Lei que define o crime militar, trata-se então do Código Penal Militar (CPM), Decreto № 1.001, de 21 de outubro de 1969, que traz em seu artigo $9^{\circ}$ a definição do que é crime militar, objeto de processo e julgamento das Justiças Militares.

Definir o crime militar não é tarefa tão fácil; para tanto, é necessário partir do geral para o específico, entender a concepção de crime é uma saída indicada. Capez (2016, p. 26) define crime, no ponto de vista material, como ato ou fato humano que, propositada ou descuidadamente, provoque lesão ou coloque em exposição a perigo bens jurídicos de significância para o coletivo e para a paz social. No ponto de vista formal, o crime é a inclusão da conduta ao tipo legal, ou seja, crime é o que o legislador define como tal. De forma mais resumida e direta, crime é todo fato típico e ilícito. Contudo, é necessário agora enveredar na definição de crime militar. A diferença central entre o crime militar e o comum sedimenta-se no bem jurídico tutelado. No crime castrense tutela-se fundamentalmente a administração militar e aquilo que é definido como princípios norteadores e basilares da hierarquia e disciplina.

O Direito Penal Militar brasileiro utiliza para preceituar o crime militar o aspecto formal, ou seja, o legislador lista por meio de lei, taxativamente, as condutas apresentadas como crime militar. De tal modo, em regra, crime militar são condutas descritas no Código Penal Militar, que, pelo seu artigo 9² define outras condições, como aquelas em razão do local e da pessoa que pratica e com quem é praticado o crime.

Classificados como crime próprio e impróprio militar, a classificação da doutrina resume de forma clara que o crime propriamente militar somente pode ser praticado por militar, assim como outros tipos penais, quais sejam, aqueles trazidos no art. $9^{\circ}$ do 
https://doi.org/10.20873/uft.2359-0106.2020.v7n2.p335-358

CPM, tendo em vista que o não militar não teria como praticar tais ilicitudes, mas exclusivamente o militar da ativa.

Já os crimes definidos como impropriamente militar, são aqueles que o civil também pode praticar quando definidos no Código Penal Castrense.

Esses crimes são apurados a partir do Inquérito Policial Militar, que é o Instituto do Direito Penal Militar que se assemelha no Direito Penal Comum ao Inquérito Policial, ou seja, tem suas semelhanças além do próprio nome, em especial a apuração do crime pela autoridade policial. Diante dessa realidade, dá-se a importância deste artigo, ao tratar do Direito Penal aplicado ao CBMTO, partindo do Estudo de Caso dos Crimes Militares cometidos pelos militares da Corporação entre 2006 e 2016. Interessa acrescentar que no Estado existem outras instituições militares além do Corpo de Bombeiros Militar, isso mostra que abordar o Direito Penal Militar no âmbito acadêmico justifica ainda mais esta pesquisa.

Definido o que é crime militar, faz-se necessário definir de forma simples quem pode ser considerado militar. A Constituição Federal, de 1988, em seu artigo 142, § $3^{\circ}$, define que os membros das Forças Armadas são denominados militares, tidos como militares da União. Ainda no texto constitucional, agora no artigo 42: "Os membros das Polícias Militares e Corpos de Bombeiros Militares, instituições organizadas com base na hierarquia e disciplina, são militares dos Estados, do Distrito Federal e dos Territórios".

Nesse sentido, os integrantes do CBMTO são considerados, de acordo com o texto constitucional, militares e assim devem ser tratados e se submeterem à legislação específica aplicada aos militares e quando do cometimento da prática de crime militar serem julgados pela Justiça Militar Estadual por tais ilicitudes. Isso significa que estão sujeitos à tutela do Direito Penal Militar, e entender a aplicabilidade dessa área do Direito tornou-se o objeto desta pesquisa.

\section{O DIREITO PENAL MILITAR APLICADO AO CORPO DE BOMBEIROS MILITAR DO ESTADO DO TOCANTINS}

\subsection{Corpo de Bombeiros Militar do Estado do Tocantins}


https://doi.org/10.20873/uft.2359-0106.2020.v7n2.p335-358

Antes de abordar sobre o Corpo de Bombeiros Militar, faz-se necessário falar quem é o profissional bombeiro militar. Este, no exercício da sua atividade-fim, coloca sua vida em risco para proteger a vida de terceiros e/ou para defender bens públicos e privados da sociedade, a fim de manter a incolumidade das pessoas, do patrimônio e do meio ambiente.

Em uma investigação sobre a palavra bombeiro e sobre a organização do Corpo de Bombeiros, constata-se serem atividades e organizações bem antigas. Conforme Campos (1999), a palavra bombeiro vem do latim e tem origem na palavra bombus, que significa bomba. Quando os incêndios começaram a tomar dimensões consideráveis, os incêndios eram controlados pelas bombas de água.

Ainda segundo Campos, a revolução industrial faz surgir a profissão bombeiro, tendo em vista que esse advento histórico trouxe consigo o desenvolvimento tecnológico e, em consequência, o risco de incêndios e acidentes. De acordo com Natividade (2009), no Brasil uma organização específica da atividade de bombeiro, só ocorreu em 2 de julho de 1856, pelo Decreto Imperial n 755 , criando com este ato 0 Corpo de Bombeiros provisórios da Corte.

O CBMTO tem sua história recente:

Superação, força de vontade, amor à vida e à profissão constroem a história do Corpo de Bombeiros Militar do Tocantins, o qual iniciou suas atividades como Companhia Independente de Bombeiros (1 ${ }^{\text {a }} \mathrm{CIBM}$ ), criada por meio de decreto (6676/92), em dezembro de 1992. À época possuía uma estrutura pequena e ligada, organicamente a Policia Militar do Tocantins, com atuação apenas nas áreas de combate a incêndios urbanos e salvamento. (CBMTO, 2019)

Criado como uma Companhia Independente da Polícia Militar do Estado do Tocantins, o Corpo de Bombeiros Militar deste Estado tornou-se instituição autônoma com sua emancipação por meio da Lei Complementar no 45, de 3 de abril de 2006:

Art. 1․ O Corpo de Bombeiros Militar do Estado do Tocantins - CBMTO, Instituição permanente, força auxiliar e reserva do Exército, organizado com base na hierarquia e disciplina militar, destina-se a preservar a ordem pública consubstanciada nas ações de tranquilidade e salubridade e paz social no Estado. 
https://doi.org/10.20873/uft.2359-0106.2020.v7n2.p335-358

O CBMTO, por força Constitucional do parágrafo 60 do artigo 144 da Carta Magna, define as polícias militares e corpos de bombeiros militares, forças auxiliares e reserva do exército, ou seja, além de serem militares estaduais, conforme o artigo 42 da Constituição, estão sujeitos aos regramentos do Direito Penal Militar, que fica a cargo da Justiça Militar da União, para os militares da União, e às Justiças Militares Estaduais, aos militares dos Estados, de acordo o § 4ํ do artigo 125 da nossa Constituição.

Incluso neste grupo, o CBMTO é uma Instituição hoje composta por 536 militares da ativa, 44 militares da reserva remunerada e 11 reformados (CBMTO, 2019), todos sujeitos ao cometimento de crimes militares, fato que num grupo heterogêneo acaba ocorrendo a infração de lei penal militar, assim como esta tem crescido na Corporação, em especial nos últimos 13 anos.

\subsection{Direito Penal Militar: Conceito}

O Direito Penal Militar, abordado neste estudo, é uma área especial do Direito Penal, que, conforme Capez (2016, p. 19):

O Direito Penal é o segmento do ordenamento jurídico que detém a função de selecionar os comportamentos humanos mais graves e perniciosos à coletividade, capazes de colocar em risco valores fundamentais para a convivência social, e descrevê-los como infrações penais, cominando-Ihes, em consequência, as respectivas sanções, além de estabelecer todas as regras complementares e gerais necessárias à sua correta e justa aplicação.

Este artigo se ocupou em tratar da particularidade do crime militar praticado pelo bombeiro militar do Corpo de Bombeiros Militar do Estado do Tocantins, até a discussão do Direito Penal Militar aplicado à Corporação. Dessarte, para conhecer o tronco principal do Direito Penal Castrense, cabe discutir e encontrar a mais próxima definição de Direito Penal Comum.

Sem teorizar mais sobre Direito Penal, a doutrina aponta que é o domínio do Direito que se ocupa com o crime e com as leis de sanção e coercibilidade a esse tipo de ato ilegal, assim como contextualiza Greco (2017, p. 6): 
https://doi.org/10.20873/uft.2359-0106.2020.v7n2.p335-358

O Direito Penal objetivo é o conjunto de normas editadas pelo Estado definindo crimes e contravenções, isto é, impondo ou proibindo determinadas condutas sob a ameaça de sanção ou medida de segurança, bem como todas as outras que cuidem de natureza penal,... excluindo o crime isentando de pena determinados tipos penais.

Tendo a finalidade de proteger os bens mais necessários para a própria sobrevivência da sociedade (GRECO, 2017, p. 4).

O Direito Penal Militar parte da doutrina para distingui-lo do Direito Penal Comum e do Direito Penal Especial; neste se inclui o direito penal militar, posto fazer menção quanto aos órgãos que devem aplicá-los jurisdicionalmente: se a norma penal objetiva pode ser aplicada pela justiça comum (estadual ou federal), sua qualificação será a de Direito Penal Comum; se, por conseguinte, somente for aplicável por órgãos especiais, constitucionalmente previstos, é relativo à norma penal especial, e aí está o Direito Penal Militar. Assim, para Romeiro (apud COSTA, 2016, p. 4):

O direito penal militar é um direito penal especial, porque a maioria de suas normas, diversamente das de direito penal comum, destinadas a todos os cidadãos, se aplicam exclusivamente aos militares, que têm especiais deveres para com o Estado, indispensáveis à sua defesa armada e à existência de suas instituições militares.

Lobão (2011, p. 33) entende que a classificação do Direito Penal Especial em função do órgão judiciário competente em aplicar o Direito Objetivo, apresenta significativa confusão entre Direito Penal Especial e Direito Processual Penal Especial. Assegura, além disso, após evidente argumentação, que o Direito Penal Militar é classificado como especial em virtude do bem jurídico protegido, o que representa a proteção das instituições militares, no tocante à particularidade da hierarquia, da disciplina, do dever e do serviço militar, acumulado à condição de militar dos autores do ato ilícito.

Segundo Romeiro (1994, p. 4), "o direito penal militar é um direito penal especial, porque a maioria de suas normas, diversamente das de direito penal comum, destinadas a todos os cidadãos, se aplicam exclusivamente aos militares, que têm 
https://doi.org/10.20873/uft.2359-0106.2020.v7n2.p335-358

especiais deveres para com o Estado, indispensáveis à sua defesa armada e à existência de suas instituições militares".

Corroborando com esta corrente doutrinária, Neves e Streifinger (2017, p. 80) afirmam:

Preferimos, partindo da mesma premissa, entender que o Direito Penal Militar é especial em razão do objeto de sua tutela jurídica: sempre a regularidade das instituições militares, seja de forma direta, imediata, seja de forma indireta ou mediata. Abarcaríamos, dessarte, como crimes integrantes desse Direito Penal especial, todos aqueles capitulados no Código Penal Militar, mesmo que impropriamente militares.

Entende-se, pois, que o Direito Penal Militar, com base nas correntes doutrinárias aqui apresentadas, constitui-se segmento especial do Direito Penal, que se destaca pelo bem jurídico tutelado e a quem se aplica a norma especial. Porém, essa asserção não pode ser entendida como pronta e acabada, tendo em vista as especialidades da aplicação da Lei Penal Castrense.

O Direito Penal Militar, para Faria (2017, p. 23), é o domínio especializado do Direito Penal que define as regras jurídicas vinculadas à proteção das instituições militares e ao cumprimento de sua finalidade prevista na Constituição Federal.

O Direito Penal Militar é também a área do Direito Penal que trata dos crimes militares e tem suas bases nas normas penais militares que, tal qual o Direito Penal Comum, dividem-se em material e formal, ambos com suas especificidades. Aqui, a base material sedimenta-se pelo que está expresso, codificada no fato de origem da relação jurídica entre o Estado, detentor do jus puniendi, e aquele que transgrediu a norma expressa, o criminoso, aquele que cometeu o crime militar.

Essa busca por definir o Direito Penal Militar garante ou exige uma visão mais acentuada do objeto de estudo desta pesquisa. Por sua vez, esta área do Direito e suas bases materiais definem qual a matéria objetiva garantida ou esperada de alguém, em que a principal norma é o Código Penal Militar.

Já as bases formais ou adjetivas, como preconizam Neves e Streifinger (2012, p. 63), caracterizam-se como as que regulam de modo geral o processo, ou seja, seu início, desenvolvimento e encerramento, o que não consiste objeto central aqui tratado. 
https://doi.org/10.20873/uft.2359-0106.2020.v7n2.p335-358

Ainda, segundo Neto (2008, online), o Direito Militar é ainda desconhecido da maioria dos doutrinadores e operadores da Ciência Jurídica, destacando-se que poucas são as Instituições de Ensino Superior que possuem em sua grade curricular referida disciplina e, mesmo assim, em muitos casos, oferecem-na tão somente como disciplina optativa. Esse esquecimento vem deixando de lado, intencionalmente o engrandecimento dessa área especializada do Direito, chegando a ponto da completa discrepância entre muitos de seus preceitos com aqueles estabelecidos pelo Direito Penal e Processual Penal Comum, uma vez que estes têm sido, continuamente, objeto de reforma de seus institutos e procedimentos; ao passo que o Direito Militar é proscrito deliberadamente dessa necessária atualização.

Diante do abordado, insta mostrar importância deste artigo em trazer para o ambiente acadêmico a discussão e a aplicabilidade do Direito Penal Militar, área do Direito que requer atenção.

\subsection{Crime Militar}

Como afirmado que o crime militar é tratado pelo Direito Penal Militar, em que ambos são objetos deste trabalho, cabe aqui tratar sobre essa modalidade de ilicitude, trazida pela Lei Penal Castrense. O Crime Militar é tratado especialmente no Código Penal Militar, e para que o crime militar seja mais bem entendido, faz-se necessário analisar de forma minuciosa a definição de crime militar transcrita na norma penal castrense, a saber, o Decreto-Lei oํ 1.001, de 1969, e suas alterações, o qual prevê hipóteses de crime militar, nos artigos 9o e 10.

Trata-se de um tipo penal, conforme a doutrina, de complexidade de entendimento que, para Capez (2016, p. 293),

Crime militar: é o definido no Código Penal Militar (Dec.-lei n. 1.001/69). Pode ser próprio e impróprio. O primeiro é o tipificado apenas no Código Penal Militar, por exemplo, dormir em serviço. O segundo também está descrito na legislação penal comum, por exemplo, homicídio, furto, roubo, estupro. (Grifo do nosso)

Sobre a definição do crime militar, Neto (2008, online): 


\section{https://doi.org/10.20873/uft.2359-0106.2020.v7n2.p335-358}

Ainda que se trate de um dos ramos mais antigos do Direito, remontando seu surgimento, no Brasil, à época do Príncipe Regente, que por Alvará de $1^{\circ}$ de abril de 1808 criou o Conselho Supremo Militar de Justiça, não se delimitou, ainda, o conceito sobre crime militar. A legislação, seja na Carta Constitucional (art. 5으, LXI, 124 e 125, § 4º) ou nos diplomas castrenses (CPPM e CPM) não o define, não sendo pacífico na doutrina e na jurisprudência os critérios para sua classificação.

Diante dessa indefinição do crime militar, destacando a dificuldade com que os doutrinadores sempre se apresentaram para defini-lo, Lobão (2011, p. 31) assegura que o:

[...] crime militar é a infração penal prevista na Lei Penal Militar que lesiona bens ou interesses vinculados à destinação constitucional das instituições militares, às suas atribuições legais, ao seu funcionamento, à sua própria existência, no aspecto particular da disciplina, da hierarquia, da proteção à autoridade militar, e ao serviço militar.

A infração penal militar é tratada pela doutrina de forma dividida, em duas categorias, destacando os crimes propriamente militares e os crimes impropriamente militares, espécies manifestamente definidas pelas teorias clássica e topográfica.

Seguindo a teoria clássica, desde sempre definiu-se que o crime militar próprio é aquele, previsto no Código Penal Militar (CPM), específico e funcional do ocupante de cargo militar, ou seja, militar, que atinge bens ou interesses das instituições militares, no aspecto da hierarquia, da disciplina, do serviço e do dever militar, e que o definido como crime militar impróprio era aquele previsto no Código Penal Militar (CPM), não sendo exclusivo e funcional do militar, e ofende bens ou interesses afetos à destinação constitucional e legal das instituições castrenses, cujo autor poderia ser militar ou civil (LOBÃO, 2011).

De outro modo, a teoria topográfica sempre distinguiu as espécies de delito, se comum ou militar, levando em conta a legislação em que estivesse definido e tipificado, se no Código Penal Comum ou no Código Penal Militar, e, no caso deste, com ou sem equivalência na norma penal comum. Signatário da teoria topográfica, assim como outros penalistas de destaque no Brasil, exibe as espécies de crime militar conforme, transcrito a seguir, Rosa (2012, p. 32): 
https://doi.org/10.20873/uft.2359-0106.2020.v7n2.p335-358

[...] os crimes propriamente militares [...] são aqueles que se encontram previstos apenas e tão somente no Código Penal Militar, como, por exemplo, a deserção, a insubmissão, o motim, o desacato a superior, entre outros, e os crimes impropriamente militares, que são aqueles que se encontram previstos tanto no Código Penal Brasileiro como também no Código Penal Militar, como exemplo, o furto, o roubo, a lesão corporal, o homicídio, a corrupção, a concussão, entre outros.

Em resumo, destaca-se que sempre se disse que crime militar próprio é aquele previsto apenas no Código Penal Militar, e que o crime militar definido como impróprio era aquele que, previsto tanto no Código Penal Militar quanto no Código Penal Comum, seria considerado militar em razão de certas circunstâncias eleitas pelo legislador.

A atual definição do Código Penal, com a alteração de 2017, apresenta-se da seguinte forma: Antes da alteração promovida pela Lei nํ 13.491, de 2017, o artigo 9º inciso II, do Código Penal Militar, era assim redigido: "Art. 9ํㅡㄴ Consideram-se crimes militares, em tempo de paz: [...] II - os crimes previstos neste Código, embora também o sejam com igual definição na lei penal comum, quando praticados" (BRASIL, 1969). Hoje, entretanto, com a redação que lhe deu a lei em comento, o artigo 9º, inciso II, do Código Penal Militar, passou a preconizar que: "Art. $9^{\circ}$ Consideram-se crimes militares, em tempo de paz: [...] II - os crimes previstos neste Código e os previstos na legislação penal, quando praticados" (BRASIL, 1969).

Assim, a Lei Penal Castrense passa a definir como crime militar em tempo de paz, aquele definido no artigo 9ํ do Código Penal Militar e os previstos na lei penal comum, quando praticados: (BRASIL, 1969):

II - os crimes previstos neste Código e os previstos na legislação penal, quando praticados: (Redação dada pela Lei no 13.491, de 2017)

a) por militar em situação de atividade ou assemelhado, contra militar na mesma situação ou assemelhado;

b) por militar em situação de atividade ou assemelhado, em lugar sujeito à administração militar, contra militar da reserva, ou reformado, ou assemelhado, ou civil;

c) por militar em serviço, em comissão de natureza militar, ou em formatura, ainda que fora do lugar sujeito a administração militar contra militar da reserva, ou reformado, ou assemelhado, ou civil;

c) por militar em serviço ou atuando em razão da função, em comissão de natureza militar, ou em formatura, ainda que fora do lugar sujeito à administração militar contra militar da reserva, ou reformado, ou civil; (Redação dada pela Lei no 9.299, de 8.8.1996) 
https://doi.org/10.20873/uft.2359-0106.2020.v7n2.p335-358

d) por militar durante o período de manobras ou exercício, contra militar da reserva, ou reformado, ou assemelhado, ou civil;

e) por militar em situação de atividade, ou assemelhado, contra o patrimônio sob a administração militar, ou a ordem administrativa militar;

f) por militar em situação de atividade ou assemelhado que, embora não estando em serviço, use armamento de propriedade militar ou qualquer material bélico, sob guarda, fiscalização ou administração militar, para a prática de ato ilegal;

\subsection{Militares Estaduais}

Os militares estaduais são aqueles pertencentes às Polícias Militares e Corpos de Bombeiros Militares nos Estados e Distrito Federal. Vale ressaltar que, em alguns estados, o Corpo de Bombeiros Militar está dentro da estrutura da Polícia Militar - são servidores públicos denominados militares subordinados ao chefe do Poder Executivo do Estado ou do Distrito Federal - e tem como princípios basilares, de acordo o artigo no 42 da Constituição Federal, de 1988, a hierarquia e disciplina, incluindo aí os membros das Polícias Militares e Corpos de Bombeiros Militares das Unidades Federativas.

Nessa vertente, Cabral (2016, p. 24) afirma que:

Os Militares Estaduais encontram respaldo no art. (42 da CF). Não existindo qualquer subordinação direta das Polícias Militares ao Exército Brasileiro em situações normais, até porque as polícias militares são subordinadas aos Governadores de Estado, conforme $\S 6$ do art. 144 da CF.

Nesta definição de militar estadual, a literatura não se distancia do artigo 42 da Constituição Federal, como relata Faria (2017, p. 23), referindo-se às Polícias Militares e aos Corpos de Bombeiros Militares, dispõe no artigo no 42 da Carta Magna que são instituições organizadas com base na hierarquia e disciplina, e que seus membros são militares dos Estados, Distrito Federal e Territórios.

\subsubsection{Bombeiros Militares}


https://doi.org/10.20873/uft.2359-0106.2020.v7n2.p335-358

Os bombeiros militares, assim como os policiais militares, como já abordado neste artigo, são militares estaduais subordinados aos governos dos Estados, Distrito Federal ou Territórios, que assim como as Forças Armadas têm como base a hierarquia e disciplina. "Ao falar das Forças Armadas, das Polícias Militares e dos Corpos de Bombeiros Militares, o texto constitucional estabelece que tais organizações são formadas com base na hierarquia e na disciplina" (MORAES, 2003, p. 25)

A Constituição Federal, de 1988, em seu artigo 144, estabelece que os Corpos de Bombeiros fazem parte do Sistema Nacional de Segurança Pública.

$\S 5$ Às polícias militares cabem a polícia ostensiva e a preservação da ordem pública; aos corpos de bombeiros militares, além das atribuições definidas em lei, incumbe a execução de atividades de defesa civil.

$\S 6^{\circ}$ As polícias militares e corpos de bombeiros militares, forças auxiliares e reserva do Exército, subordinam-se, juntamente com as polícias civis, aos Governadores dos Estados, do Distrito Federal e dos Territórios.

Os Corpos de Bombeiros Militares têm suas funções constitucionais, além das estabelecidas em lei, e a seus integrantes, aos bombeiros militares, considerados militares estaduais, incumbe a missão de realizar as funções da instituição a que pertencem.

Seguindo nessa vertente, o Corpo de Bombeiros Militar do Estado do Tocantins tem-se fundamentado na Constituição Estadual do Estado do Tocantins, de 1989, que:

Art. 114. A segurança pública, dever do Estado, direito e responsabilidade de todos, é exercida para a preservação da ordem pública e incolumidade das pessoas e do patrimônio, pelos seguintes órgãos estaduais:

I - Polícia Civil;

II - Polícia Militar;

III - Corpo de Bombeiros Militar.

$\S 1 \%$. A Polícia Militar e o Corpo de Bombeiros Militar são regidos por legislação especial, que define sua estrutura, deveres, prerrogativas de seus integrantes, de modo a assegurar a eficiência de suas atividades e atuação harmônica, observados os preceitos da Constituição Federal.

Os bombeiros militares do Tocantins, integrantes do Corpo de Bombeiros Militar, atuam no cumprimento das funções constitucionais; no tocante à legislação penal, 
https://doi.org/10.20873/uft.2359-0106.2020.v7n2.p335-358

estão sujeitos à lei penal castrense. Além das funções constitucionais, o Corpo de Bombeiros Militar do Estado do Tocantins, por meio dos seus militares, tem de cumprir o estabelecido na sua Lei de Organização Básica (LOB), Lei Complementar no 45, de 3 de abril de 2006.

Além do estabelecido, no artigo 1ํ da Lei de Organização Básica do Corpo de Bombeiros Militar (já citado neste artigo), compete ao Corpo de Bombeiros Militar do Estado do Tocantins, o planejamento de ações emergenciais ou de socorro no âmbito de proteção e defesa civil; o estabelecimento de normas relativas à incolumidade das pessoas e do patrimônio, dentre outras atividades estabelecidas nesta lei e em outras normas infraconstitucionais. Os bombeiros militares são os agentes do cumprimento dessas atividades.

Em razão da condição de pertencerem a Forças Auxiliares e Reservas do Exército Brasileiro, os bombeiros militares, com base na legislação e na literatura aqui apresentada, são militares estaduais, regidos pela Legislação Penal Militar, bem como pela Processual Penal Militar e julgados pela Justiça Militar Estadual.

\subsection{Justiça Militar}

Considerando a existência do Direito Penal Militar e Processual Penal Militar que trata dos Crimes Militares, presume-se a existência da Justiça Militar; porém, Neves e Streifinger (2017, p. 62) afirmam que é "Interessante notar que a existência de um Direito Penal militar não importa necessariamente na instalação de uma Justiça Militar competente para julgar todos os crimes militares perpetrados". Mas para julgar os crimes militares, a norma instituiu a Justiça Militar, que a Constituição, de 1988, trouxe da seguinte forma:

Art. 122. São órgãos da Justiça Militar:

I - o Superior Tribunal Militar;

II - os Tribunais e Juízes Militares instituídos por lei.

Art. 125. Os Estados organizarão sua Justiça, observados os princípios estabelecidos nesta Constituição.

...

$\S 4^{\circ}$ Compete à Justiça Militar estadual processar e julgar os militares dos Estados, nos crimes militares definidos em lei e as ações judiciais contra atos disciplinares militares, ressalvada a competência do júri quando a vítima for civil, cabendo ao tribunal competente decidir sobre a perda do posto e da patente dos oficiais e da graduação das praças. 
https://doi.org/10.20873/uft.2359-0106.2020.v7n2.p335-358

$\S 5^{\circ}$ Compete aos juízes de direito do juízo militar processar e julgar, singularmente, os crimes militares cometidos contra civis e as ações judiciais contra atos disciplinares militares, cabendo ao Conselho de Justiça, sob a presidência de juiz de direito, processar e julgar os demais crimes militares.

Rocha (2011, [s.p.]) reorganiza o texto legal transcrito da seguinte forma: "A Justiça Militar nos Estados, por sua vez, é constituída pelos juízes de direito e pelos Conselhos de Justiça e, em segundo grau, pelo Tribunal de Justiça ou pelo Tribunal de Justiça Militar nos Estados, em que o efetivo seja superior a vinte mil integrantes (artigo 125, § $3^{\circ}$, da Constituição), tendo como competência apreciar os crimes militares praticados por policiais militares e bombeiros militares". Assim, entende-se que, no caso em tela, os crimes a serem analisados foram julgados pela Justiça Militar Estadual, que no Tocantins está dentro da estrutura do Tribunal de Justiça do Estado, que julga os militares estaduais quanto aos crimes militares pelo Conselho da Justiça Militar Estadual (TJTO, 2019).

Ainda conforme Rocha, "A Justiça Castrense Federal tem competência para julgar os membros das Forças Armadas. A Justiça Militar Federal é composta pelos Conselhos de Justiça, especial e permanente. Por sua vez, o Superior Tribunal Militar tem competência para julgar as apelações e os recursos das decisões dos juízes de primeiro grau da Justiça Militar da União, à luz do artigo 123 da Constituição". Aqui, são as circunstâncias que envolvam qualquer crime militar praticado pelos integrantes das Forças Armadas.

À justiça militar estadual cabe julgar os crimes militares praticados pelos militares estaduais; para a Justiça Militar da União, os praticados pelos militares das Forças Armadas. Quanto ao cidadão civil, Carvalho (2010, [s.p.]) traz, verbis:

O cidadão civil é julgado na Justiça Militar da União, quando comete crimes definidos como militares em coautoria com integrantes das três armas. À Justiça Militar dos Estados compete o julgamento dos integrantes das chamadas Forças Auxiliares, ou seja, as organizações militares estaduais - policiais e bombeiros - também, nos crimes militares definidos em lei. Do mesmo modo, na Justiça Militar, são julgados os militares da reserva, os reformados e os ex-militares (ou excluídos) que tenham cometido crime militar ainda na ativa. 
https://doi.org/10.20873/uft.2359-0106.2020.v7n2.p335-358

O militar é aquele cidadão investido na carreira em uma das Forças Armadas: Marinha, Exército e Força Aérea, conforme o artigo 142, § 3o, da Constituição Federal, de 1988: "os membros das forças armadas são denominados militares, aplicando-seIhes, além das que vierem a ser fixadas em lei, as seguintes disposições... Quanto aos militares estaduais, ainda na Carta Magna, o artigo 42, caput, assim assevera: "os membros das polícias militares e corpos de bombeiros militares, instituições organizadas com base na hierarquia e disciplina, são militares dos estados, do distrito federal e dos territórios", rol em que se incluem os bombeiros militares do estado do Tocantins, os quais terão os crimes praticados por eles analisados neste trabalho.

Segundo escrevem Neves e Streifinger (2012, p. 77),

é preciso também ter em vista que as instituições militares, as Forças Armadas, as Polícias Militares e os Corpos de Bombeiros Militares, têm missões de suma importância na preservação das liberdades públicas, porquanto a elas cabem a defesa da Pátria, a garantia dos poderes constitucionais, da lei e da ordem, o policiamento ostensivo preventivo, a preservação da ordem pública e as atividades de defesa civil.

Assim, aduz-se que os autores queiram reforçar a importância das instituições, da proteção trazida pela norma penal, mostrar a importância das instituições o que leva a entender o porquê da Justiça Militar, no tocante aos militares e às instituições militares.

Ainda, teorizando Neves e Streifinger (2012, p. 158):

Ao contrário do que sucede com a Justiça Militar da União, cujo âmbito de incidência, por expressa previsão constitucional - art. 124, caput, da CF/88 - abrange também os civis, a competência da Justiça Militar Estadual abrange apenas os policiais e os bombeiros militares.

Esta afirmação coaduna com o que pensa Oliveira (2012, [s.p.]):

No que toca à Justiça Militar Estadual, está a missão de tutelar os valores afetos às Polícias Militares e aos Corpos de Bombeiros Militares, competindo-lhe processar e julgar os crimes militares definidos em lei, desde que praticados por membros das corporações mencionadas.

\subsection{Inquérito Policial Militar}


https://doi.org/10.20873/uft.2359-0106.2020.v7n2.p335-358

O Inquérito Policial Militar é um procedimento inquisitorial em que não há acusado, e sim indiciado, pessoa sobre a qual recaem os indícios de crime. Este Inquérito é procedimento preparatório ou preliminar da ação penal (MANOEL, 2008, p. 29). Assim, o Inquérito Policial é todo procedimento policial destinado a reunir os elementos necessários à apuração da prática de uma infração penal e de sua autoria. Trata-se de uma instrução provisória, preparatória, informativa, em que se colhem elementos por vezes difíceis de serem obtidos na instrução jurídica, como auto de flagrante, exames periciais etc. (CAMARGO, 2006 apud MIRABETE, 2005, p. 82).

O Inquérito Policial Militar (IPM), que é o Instituto do Direito Penal Militar e se assemelha no Direito Penal Comum ao Inquérito Policial, tem suas semelhanças, além do próprio nome, em especial à apuração do crime pela autoridade policial. O Inquérito Policial Militar é o instrumento utilizado para apurar as infrações militares em que se vislumbram indícios de crime militar.

Observados indícios de ocorrência de infração penal castrense, deverá ser instaurado o IPM pelas autoridades de Polícia Judiciária Militar definidas no artigo $7^{\circ}$ do CPPM. Tal instauração poderá ser delegada, sempre que necessário, para um Oficial da ativa, superior hierárquico do militar que se supõe tenha praticado a infração penal. (MORAES, 2003, p. 152)

Os Inquéritos Policiais Militares, conforme rege o Código de Processo Penal Militar, têm o prazo de quarenta dias, prorrogável por mais vinte dias para indiciado solto, e vinte dias para indiciado preso. Ainda quanto à definição e finalidade do Inquérito Policial Militar, o artigo 9º do Código de Processo Penal Militar discorre sobre a finalidade deste Inquérito, que é a apuração sumária de fato, a qual, nos termos legais, configure crime militar, e de sua autoria. Tem o caráter de instrução provisória, cuja finalidade precípua é a de ministrar elementos necessários à propositura da ação penal. O parágrafo único do artigo citado assegura que são, porém efetivamente instrutórios da ação penal os exames, as perícias e as avaliações, realizados regularmente no curso do inquérito por peritos idôneos e com obediência às formalidades previstas neste Código. (BRASIL, 1969) 
https://doi.org/10.20873/uft.2359-0106.2020.v7n2.p335-358

Ao discutir a importância do Inquérito Policial, faz-se necessário compreender que ele é utilizado como elemento de investigação sobre a autoria e materialidade da infração penal castrense. Instrumento destinado ao detentor da ação penal com a finalidade de auxiliar este a subtrair os elementos necessários ao oferecimento da denúncia ou da queixa-crime, completa Marreiros, Rocha e Freitas (2015).

\section{CRIMES MILITARES PRATICADOS PELOS BOMBEIROS MILITARES DO CORPO DE BOMBEITOS MILITAR DO ESTADO DO TOCANTINS (CBMTO)}

A amostragem selecionada foi a análise de todos os Inquéritos instaurados, de 2006 até 2016. Isso porque 2006 foi o ano em que o Corpo de Bombeiros Militar do Estado do Tocantins foi emancipado, ou seja, separou-se da Polícia Militar do Estado do Tocantins, e 2016 foi o ano de inclusão da última turma de soldados da Corporação (CBMTO, 2019). Assim, a amostragem engloba todos os bombeiros militares do Tocantins que já serviram (estão hoje na reserva remunerada ou reforma) e os militares da ativa.

Foram instaurados dezenove Inquéritos Policiais Militares envolvendo militares do Corpo de Bombeiros Militar, após 20 de abril de 2006, sendo dezoito no âmbito do Corpo de Bombeiros e um no âmbito da Polícia Militar, envolvendo um bombeiro militar lotado no Centro Integrado de Operações Aéreas (CIOPAER).

Nem todos os inquéritos instaurados chegaram a indícios de existência de crime militar, conforme a conclusão exaurida pelo encarregado do Inquérito. Cabe aqui ressaltar que a persecução penal desenvolver-se-á, de forma ordinária, em duas fases, a saber: investigação preliminar e devido processo judicial. De maneira geral, a primeira fase da investigação preliminar se dará por meio de um inquérito policial militar, mas não regra irrestrita. Há os fatos em que o Inquérito Policial Militar não será cogente, não havendo aí, portanto, a necessidade de investigação do fato-crime, nem de sua autoria. Há também os casos em que os elementos necessários de informação podem ter sido extraídos de forma efetiva por outra forma ou meios, tais quais: inquéritos civis públicos, processos administrativos disciplinares, sindicâncias etc. Assim, verifica-se que o inquérito policial restará por escusado. 
https://doi.org/10.20873/uft.2359-0106.2020.v7n2.p335-358

Não foi verificada, no intervalo de tempo eleito, nenhuma situação em que o Inquérito Policial Militar foi dispensado, assim chega-se ao entendimento de que, dos fatos apurados na totalidade dos casos, foi vislumbrada a necessidade de apuração por meio deste Inquérito.

Os crimes militares apurados nos Inquéritos instaurados pelo Corpo de Bombeiros Militar do Estado do Tocantins foram de natureza militar por essência, havendo os crimes militares próprios e os impróprios já abordados no capítulo sobre Inquérito Policial Militar. Do conjunto de inquéritos analisados, o primeiro fato ocorrido se deu em 26 de setembro de 2006 e o último em 5 de novembro de 2015, fato este apurado por Inquérito Policial Militar, em 2016. Interessante notar que parte dos Inquéritos analisados foi instaurada a partir de informações de Sindicâncias em curso, cinco no total.

O perfil dos indiciados, $92,60 \%$ dos 27 indiciados eram homens, ressaltando que, por previsão legal, o efetivo do Corpo de Bombeiros Militar é obrigatoriamente de $10 \%$ para feminino quando no ingresso ${ }^{4}$. Este quantitativo pode aumentar ou diminuir quando da ida para reserva pelo efetivo masculino e feminino, ou saídas a pedido. Esse é um percentual aparentemente reduzido. Contudo, quer se crer seja razoável (MENDONÇA \& NUNES, 2013, p. 28).

Dentre os indiciados, $48,20 \%$ estavam na faixa etária entre os 31 e 40 anos, sendo ainda $37,00 \%$ na faixa etária de 18 a 30 anos; 7,40\% entre 41 e 50 anos, e a mesma quantia para aqueles com idade superior a 50 anos.

Quanto à hierarquia, $44,44 \%$ eram oficiais de todos os postos; o restante era composto pelas praças. Quanto aos ciclos, os números seguem da seguinte forma: 7,40\% para oficiais superiores; 18,52\% oficiais intermediários (capitães), número igual para oficiais subalternos; quanto às praças: $14,80 \%$ no ciclo de subtenentes e sargentos; e 40,76\% para o ciclo de cabos e soldados.

No tocante ao número de indiciados por Inquérito Policial Militar, a maioria, $73,70 \%$, foi com apenas um indiciado; já o percentual de $5,26 \%$ foi tanto para inquéritos

\footnotetext{
${ }^{4}$ Artigo 11, § 10 Lei Estadual 2.578, de 20 de abril de 2012: Estatuto dos Policiais Militares e Bombeiros Militares do Estado do Tocantins: $\S 10$. As vagas para ingresso na Corporação, destinadas ao sexo feminino, são limitadas a $10 \%$ do total disponibilizado no concurso público.
} 
https://doi.org/10.20873/uft.2359-0106.2020.v7n2.p335-358

com dois, cinco e sem indiciados; e 10,52\% para os inquéritos com três indiciados. Quanto aos prazos, $73,70 \%$ foram apurados sem prorrogação; os outros $26,30 \%$ foram concluídos após prorrogação de prazos, sendo por diversos motivos estas prorrogações.

Quanto à situação se em serviço, ou não; se em razão do serviço, ou não, temse a seguinte realidade quanto aos Inquéritos Policiais Militares analisados: $73,70 \%$ militares em serviço; e 26,30\% estando o militar no seu horário de folga. Quanto se em razão do serviço, ou não, 63,15\% em razão do serviço; os demais não, os fatos não foram praticados em razão do serviço.

O encarregado ao encerrar o Inquérito Policial Militar tem de expor em seu relatório se há principalmente a existência de indícios de crime, assim, da análise feita, os números a que chegaram os encarregados, são: $63,15 \%$ concluíram pela existência de indícios de Crime Militar; 5,26\% pela existência de indícios de crime militar e crime comum; e 31,58\% concluíram pela inexistência de crime.

Quanto ao andamento processual ou concluído, arquivado, transitado em julgado ou em tramitação, três inquéritos resultaram em processos que ainda estão em tramitação; dezesseis foram arquivados, baixados ou o processo transitou em julgado. Desses números, em uma análise mais apurada, verifica-se que $31,58 \%$ foram solucionados por transação penal ${ }^{5} ; 42,11 \%$ arquivados sem oferecimento de denúncia; em $5,26 \%$ os réus foram absolvidos, este mesmo percentual se deu para inquérito arquivado pela inexistência de crime e indiciado; o restante, 15,79\% está em tramitação no Conselho da Justiça Militar Estadual do Tocantins.

\section{CONSIDERAÇÕES FINAIS}

\footnotetext{
${ }^{5}$ Pode se dizer que a Transação Penal é um instituto despenalizante previsto no art. 98, inciso I, da CF/88, e característico da Lei n. 9.099/95 (Lei dos Juizados Especiais), uma vez que substitui a pena privativa de liberdade. O oferecimento ou não da transação penal, claro que observados os requisitos legais para tanto, é de competência do titular da ação penal, ou seja, do Ministério Público. Assim, diante da representação, ou sendo a ação penal pública incondicionada, e não sendo caso de arquivamento, pode o representante do Ministério Público propor, antes do oferecimento da denúncia, a transação penal, que consistirá na aplicação de penas restritivas de direitos ou multa. (ROCHA, 2015 online)
} 
https://doi.org/10.20873/uft.2359-0106.2020.v7n2.p335-358

Diante de todas as análises feitas e de todos os argumentos, fundamentações, dados e informações apresentadas, infere-se que o Direito Penal Militar é um domínio do Direito constantemente aplicado no âmbito do Corpo de Bombeiros Militar do Estado do Tocantins, o que acaba, embora os números apresentados sejam considerados abaixo da média, fazendo parte da vida castrense dos bombeiros militares do Tocantins.

A análise quanto à faixa etária, sexo, ciclos, postos e graduações, situação se em serviço, ou não, representa números que correspondem à realidade da Corporação e apresenta um retrato aproximado de seu efetivo.

Fica observado, que dos fatos apurados, a maioria ocorreu em serviço, e em razão do serviço do bombeiro militar; destes casos, quase que sua totalidade foi solucionada, e é fato a se registrarem duas correlações, a efetividade da apuração quanto ao resultado de conclusão para inexistência de crime militar, seis inquéritos, e o arquivamento sem oferecimento da denúncia, oito inquéritos, fato este que leva a entender que houve eficiência quanto à apuração.

Um segundo ponto a se registrar como fato, até mesmo para ser abordado de forma mais aprofundada noutro trabalho, é a aplicabilidade da Transação Penal, no âmbito da Justiça Militar Estadual, pois, embora a doutrina tenha correntes divididas quanto à transação penal, aquela tem aplicado este instituto, resolvendo, assim, grande parte dos processos abertos. Essa aplicação da transação penal pode ser vista como fator positivo, tanto para a Justiça Militar Estadual quanto para o militar envolvido, bem como para a Corporação.

Interessante notar que os militares indiciados precisam de defesa e seja esta qualificada, para que o acusado não fique indefeso; porém, embora não muito debatido, mas como um objetivo implícito deste trabalho, é preciso discutir o Direito Penal Militar no âmbito acadêmico da Universidade Federal do Tocantins (UFT), para que este tema seja mais bem estudado, abordado ou até mesmo oferecido como disciplina na grade do curso de Direito desta Universidade.

Por fim, cabe dizer que o Direito Penal Militar, no âmbito do Corpo de Bombeiros Militar do Estado do Tocantins, tem sua base na apuração dos fatos por meio dos Inquéritos Policiais Militares, que, conclusos, são encaminhados para o juiz-presidente 
https://doi.org/10.20873/uft.2359-0106.2020.v7n2.p335-358

do Conselho da Justiça Militar Estadual que se encarrega de, após denúncia, ou não, do Ministério Público Estadual, iniciar o processo de julgamento ou arquivamento do procedimento inquisitório. O Direito Penal Militar no âmbito da Justiça Militar Estadual do Tocantins tem sido aplicado de maneira efetiva, segundo os dados levantados, objetivando resguardar as instituições para as quais visam proteger, bem como o próprio direito dos militares.

\section{REFERÊNCIAS}

BRASIL. Código Penal. Decreto-Lei no 2.848, de 7 de dezembro de 1940. Vade mecum. São Paulo: Saraiva, 2018.

Código Penal Militar. Decreto-Lei no 1.001, de 21 de outubro de 1969. Vade mecum. São Paulo: Saraiva, 2018.

. Código de Processo Penal Militar. Decreto-Lei no 1.002, de 21 de outubro de 1969. Vade mecum. São Paulo: Saraiva, 2018.

2018.

. Lei no 9.099, de 26 de setembro de 1995. Vade mecum. São Paulo: Saraiva,

. Constituição da República Federativa do Brasil de 1988. Vade mecum. São Paulo: Saraiva, 2018.

CABRAL, Syllas. Militares federais e estaduais: uma abordagem de seus aspectos gerais em um breve ensaio. Disponível em: https://syllasbz.jusbrasil.com.br/artigos/405565274/militares-federais-eestaduaisuma-abordagem-de-seus-aspectos-gerais-em-breve-ensaio. Acesso em: 25 de agosto de 2019.

CAMARGO, Felipe Feliman. O Valor Probatório do Inquérito Policial. Unival - Centro de Ciências Jurídicas, Políticas e Sociais - CEJURPS. Itajaí Maio/2006 Disponível em: http://siaibib01.univali.br/pdf/Felipe\%20Feliman\%20Camargo.pdf Acesso em: 14 ago. 2019.

CAMPOS, Cristiane Coelho. $O$ Estresse Profissional e suas implicações na qualidade de vida dos Bombeiros Militares de Florianópolis. 1999. $180 \mathrm{f}$. Monografia (Serviço Social) - Universidade Federal de Santa Catarina, Florianópolis, 1999. 
CAPEZ, Fernando. Curso de direito penal. Volume 1. 15. ed. São Paulo: Saraiva, 2016.

CARVALHO, Maria Beatriz Andrade. A Justiça Militar Estadual: estrutura, competência e fundamentos de existência. Revista Jus Navigandi, ISSN 1518-4862, Teresina, ano 15, n. 2651, 4 out. 2010. Disponível em: <https://jus.com.br/artigos/17546>. Acesso em: 25 jun. 2019.

COSTA, Leandro dos Santos. Constitucionalização do direito penal e do direito penal militar. Disponível em: https://jus.com.br/artigos/53537/constitucionalizacao-dodireito-penal-e-do-direito-penal-militar. Acesso em 21 de agosto de 2019.

FARIA, Marcelo Uzeda de. Direito Penal Militar. 5 ed. São Paulo: Editora Jus Podivm, 2017.

GRECO, Rogério. Curso de direito penal: parte geral - v. 1. 19. ed. Niterói: Impetus, 2017.

LOBÃO, Célio. (2011). Comentários ao código penal militar: parte geral. Rio de Janeiro, Forense. v. 1.

LOBÃO, Célio. Direito penal militar. Direito penal especial. Direito penal comum. Direito processual especial. In: Direito militar, cit., p. 38-45.

MANOEL, Elio de Oliveira. Manual de Polícia Judiciária Militar: teoria \& prática. 2, ed. Curitiba: Opta, 2008.

MARREIROS, Adriano Alves; ROCHA, Gilherme; FREITAS, Ricardo. Direito Penal Militar: Teoria e Prática. 1. ed. São Paulo: Editora Método, 2015.

MENDONÇA, Márcio Antônio Barbosa de, NUNES, Sérgio. Estatuto PM - BM Comentado (Artigo por Artigo). Gurupi: Editora Veloso, 2013.

MORAES, Reinaldo Zychan. Os crimes militares e o inquérito policial militar: Uma visão prática. São Paulo: Livraria Científica Ernesto Rechmann, 2003.

NATIVIDADE, Michelle Regina da. Vida em Risco: A identidade profissional dos bombeiros militares. 2008. $10 \mathrm{f}$. Artigo (Psicologia e Sociedade) - Universidade do Sul de Santa Catarina, Palhoça, 2009.

NETO, Benevides Fernandes. Crime militar e suas interpretações doutrinárias e jurisprudenciais. In: Âmbito jurídico, Rio Grande, XI, n. 60, dez 2008. Disponível em: 
juridico.com.br/site/index.php?n_link=revista_artigos_leitura\&artigo_id=4586>. Acesso em: 21 abr. 2019.

NEVES, Cícero Robson Coimbra, STREIFINGER Marcello. Manual de direito penal militar. 2, ed. São Paulo: Saraiva, 2012.

ROCHA, Maria Elizabeth Guimarães Teixeira. A Justiça Militar da União na Constituição Brasileira de 1988. In: Âmbito Jurídico, Rio Grande, XIV, n. 84, jan. 2011. Disponível em: $<$ http://www.ambitojuridico.com.br/site/index.php?n link=revista artigos leitura\&artigo id=8796>. Acesso em: 28 jun. 2019.

ROCHA, Valter Pereira da. A Aplicabilidade da Transação Penal na Justiça Militar. In: Jus Navigandi, abril $2015 . \quad$ Disponível em: https://jus.com.br/imprimir/38479/aplicabilidade-da-transacao-penal-na-justica-militar. Acesso em: 15 ago. 2019.

ROMEIRO, Jorge Alberto. Curso de direito penal militar: parte geral. São Paulo: Saraiva, 1994.

ROSA, Paulo Tadeu Rodrigues. (2012). Código penal militar comentado: artigo por artigo. 2. ed., Belo Horizonte, Líder.

TOCANTINS. Constituição do Estado do Tocantins de 1989: Disponível em: https://www.al.to.leg.br/arquivos/documento_50244.PDF\#dados. Acesso em: 20 ago. 2019.

. Lei Complementar 045, de 03 de abril de 2006: Lei de Organização Básica do Corpo de Bombeiros Militar do Estado do Tocantins. Disponível em: https://www.al.to.leg.br/arquivos/ 33516.pdf. Acesso em: 20 ago. 2019.

. Lei no 2.578, de 20 de abril de 2012: Estatuto dos Policiais Militares e Bombeiros Militares do Estado do Tocantins. Disponível em: https://www.al.to.leg.br/arquivos/lei 2578-2012 43239.pdf. Acesso em: 20 ago. 2019. 